\title{
Theoretical Regulations and Institutional Features of Financing Arts
}

\author{
N.A. Burakova ${ }^{\mathrm{a}}$ O.A. Slavinskaya ${ }^{\mathrm{b}}$ \\ Institute of Economics of the Russian Academy of Sciences, Moscow, Russia \\ ${ }^{\mathrm{a}}$ https://orcid.org/0000-0001-8902-193X; ${ }^{\mathrm{b}}$ https://orcid.org/0000-0002-6683-4812
}

\begin{abstract}
The authors have analyzed organizations of the performing arts sector, one of the classic key benefits in the economy. The empirical research has been based on the economic pattern of "cost disease". A unique statistical database has been compiled on the basis of the information database of the Federal State Statistics Service and the Ministry of culture of the Russian Federation. The research presents the Baumol's indices calculations updated in 2001-2015. There have been confirmed such symptoms of Baumol's cost disease as: labor productivity in cultural organizations lagging behind the average regional rate, super-inflationary growth for ticket prices in theaters, and catch-up wage growth in the theater in relation to the average wage level in the region. The author's approach to the analysis of the Baumol's cost disease is a modification of the overall Baumol index as a replacement for the income deficit indicator for the share of expenses covered by budget funds. New results have been obtained for estimating the income deficit and the share of expenditures covered by public funding by using the panel data model and quantile regression. The practical value of this research is the systematization of budgetary and extra-budgetary support for cultural organizations. New institutions of financial support such as the institute of participatory budgeting and the institution of individual budget allocations have been suggested to create favorable environment for the development of cultural organizations

Keywords: cultural organizations; lagging labor productivity; income deficit; cost disease model; wages; financial institutions; budgetary subsidy
\end{abstract}

For citation: Burakov N.A., Slavinskaya O.A. Theoretical regulations and institutional features of financing arts. Finansy: teoriya i praktika = Finance: Theory and Practice. 2018;22(6):25-38. DOI: 10.26794/2587-5671-2018-22-6-25-38

\section{Теоретические закономерности и институциональные особенности финансирования искусства}

\author{
Н.А. Бураков ${ }^{a}$, О.А. Славинская \\ Институт экономики РАН, Москва, Россия \\ ${ }^{\text {a }}$ https://orcid.org/0000-0001-8902-193X; ${ }^{\text {b }}$ https://orcid.org/0000-0002-6683-4812
}

\begin{abstract}
АННОТАЦИЯ
Авторы анализируют функционирование учреждений сферы культуры и искусства, которая является одним из классических примеров опекаемых благ в экономике. Эмпирическое исследование опирается на экономическую закономерность «болезнь цен». Составлена уникальная статистическая база данных на основе информации Росстата и информационной базы данных Министерства культуры РФ. В исследовании обновлены расчеты индексов Баумоля за период 2001-2015 гг. Получено подтверждение наличия таких симптомов «болезни Баумоля», как: отстающая от среднерегионального темпа производительность труда в учреждениях культуры, сверхинфляционный рост цен на билеты в театрах, догоняющий рост заработных плат в театре по отношению к среднему уровню заработных плат в регионе. Авторским подходом к анализу «болезни цен» Баумоля можно считать модификацию общего индекса Баумоля в виде замены показателя дефицита дохода на долю расходов, покрываемых за счет бюджетных средств. Получены новые результаты оценки дефицита дохода и доли расходов, покрываемых за счет государственного финансирования, с использованием модели панельных данных и квантильной регрессии. Практическая ценность данного исследования состоит в систематизации механизмов бюджетной и внебюджетной поддержки учреждений искусств. В качестве основы для создания благоприятной среды развития организаций культуры предложены такие новые институты финансовой поддержки, как институт партисипативного бюджетирования и институт индивидуальных бюджетных назначений. Ключевые слова: учреждения культуры; отстающая производительность труда; дефицит доходов; модель «болезни цен»; заработная плата; финансовые институты; бюджетная субсидия
\end{abstract}

Для цитирования: Н.А. Бураков, О.А. Славинская. Теоретические закономерности и институциональные особенности финансирования искусства. Финансы: теория и практика. 2018;22(6):25-38. DOI: 10.26794/2587-5671-2018-22-6-25-38 


\section{INTRODUCTION: THE THEORETICAL LANDSCAPE}

After the crises of the 1990s, the social sector of the Russian economy in the new century has been influenced by the dominant idea to reduce it both in finance and in labor force. It has a particularly negative impact on its humanitarian component. Increasing "financial starvation" of institutions of education, health, science and culture has negative impact on personnel policy and on the quality of goods produced [1].

This situation is best seen in the performing arts sector in some countries. Many researchers point to great difficulties in fulfilling the obligations of cultural institutions in covering their expenses that combined with the rise in public spending on culture and dependence on budget financing [2]. At the same time, the managers of these organizations have to look for alternative ways to achieve a positive economic effect, as they have limited tools to increase productivity. They have no real opportunity to significantly increase production of goods by improving the qualification of employees, production process or increasing its scale. Such phenomenon is called the effect of Baumol's cost disease.

The specificity of production of goods, subjected to the effect of cost disease, is that labor productivity in the performing arts can't grow without reducing the quality of products and objectively lags behind the growth of labor productivity in the economy as a whole [3]. This mechanism entails a rapid increase of the production costs of cultural goods relative to the increase in the price of the final product. The consequence of this economic effect, confirmed by empirical studies [4-8] is an objective unprofitability of cultural organizations. However, in some sources [9], the authors suggest that such mechanisms of economic modeling and productivity optimization as marketing and management, as well as the development and creation of a new paradigm of culture can overcome the "disease of inefficiency" and "cure" any "cost disease".

There are also studies $[10,11]$ providing examples of empirical analysis of demand for cultural goods. At the same time, the works also cover the topic of goods in cultural heritage, but most works are devoted to the analysis of demand for performing arts products. Among the main hypotheses tested in the researches it is possible to think about the elasticity of demand for price, income, the price of possible substitutes, as well as the dependence of the current demand for cultural goods on the history of past cultural consumption.

In early works $[3,12,13]$, proofs of various hypothesis about the elite status of the performing arts product consumers were confirmed ${ }^{12}$. The analysis has been based on the study of the level of education, income and profession of these consumers. The paper $[10,12]$ has provided a summary table of more than thirty studies, among which [14-21] can be marked. The table has presented the results of testing the hypothesis that high elasticity demand for performing arts and such goods in general are luxury products. This hypothesis has been confirmed by only 4 studies out of total number, while in other 5 experiments mixed results have been obtained. Therefore, the demand was elastic only for certain types of viewers, organizations and events. It is important to note that most of the works have used aggregated data.

In some publications the authors have used more detailed data: [22] consumers have been divided by income level; [23] demand has been divided by types depending on the seats in the theatre's auditorium; $[18,24]$ consumers have been divided into two groups depending on whether they purchased a season ticket or not. The approach to this problem should also be noted. Due to it, the analysis of the cross elasticity of demand for performing arts has been carried out [25].

In the abovementioned works, the authors have managed to empirically prove only some hypotheses that they put forward in relation to the demand for performing arts services. Among them are:

- performing arts products are not necessarily perceived as a luxury product [26];

- demand for performing arts services has mostly low elasticity at its own cost and a positive coefficient of cross elasticity at the price of some goods.

However, it should be noted that there are still open questions concerning the verification and interpretation of low price elasticity of demand, elasticity of income. It is also necessary to find out what goods can be considered as substitutes or complementary in relation to performing arts products, as well as the relationship between the standard socio-economic factors that determine demand, and social characteristics such as, for example, "style" and specificity of consumer life.

\section{CHARACTERISTICS OF THE RESEARCH}

The conditions of the current decline in the Russian economic growth create an opportunity to study this

\footnotetext{
${ }^{1}$ Ford Foundation. The Finances of the Performing Arts. Vol. II: A Survey of the Characteristics and Attitudes of Audiences for Theater, Opera, Symphony, and Ballet in 12 US Cities. Ford Foundation. New York. 1974.

${ }^{2}$ National Research Center of the Arts. Inc. Americans and the Arts: A Survey of the Attitude toward and Participation in the Arts and Culture of the United States Public. National Research Center of the Arts. Inc. New York. 1976.
} 


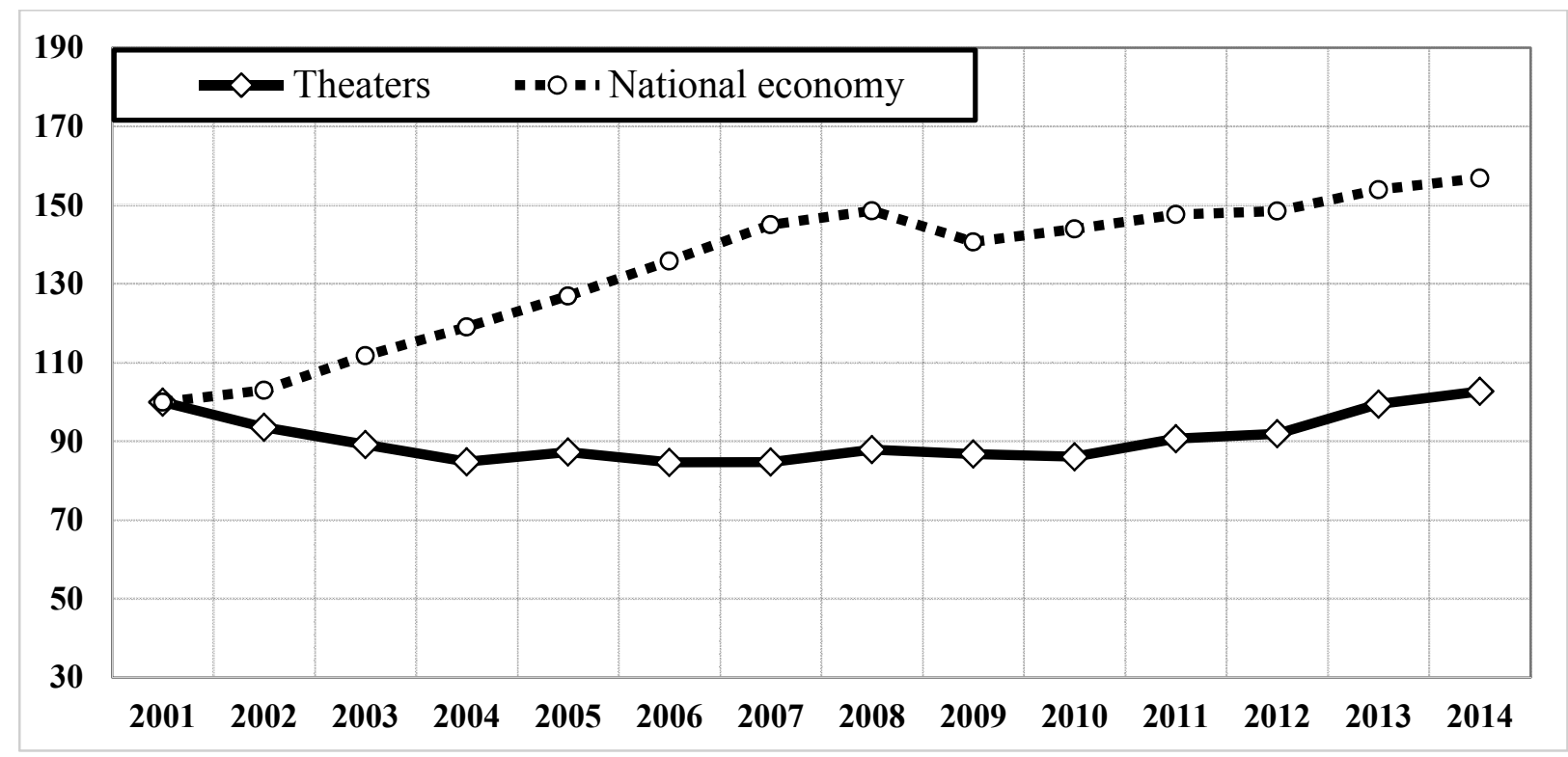

Fig. 1. Dynamics of labor productivity in theaters and in the economy of the Russian Federation (2001=100\%)

Source: the calculations done by the author.

effect. In this regard, according to the authors of this research, it is relevant to analyze the impact of the price level when visiting cultural institutions on the demand for these goods. At the same time, the authors have used A. Ya. Rubinshteyn's idea, presented in work "Patronized goods in culture: features and consequences of cost disease" [6]. The objective of the work, according to the authors, is the confirmation or refutation of the early hypotheses of existing lagging labor productivity in one of the types of performing arts, namely in theaters. This requires a special approach to financing of this economic sector. The study period from 2001 to 2014 allows for testing in the context of a single course of reform in the humanitarian sector in the country.

Considering the need for a special database, the information database of the Ministry of Culture of the Russian Federation has been selected as a major source. Some regional indicators have also been taken from the statistical base of Russian Federal State Statistics Service. The study includes annual data on all state theaters and the economy of the country as a whole, that combine values of the following indicators:

- gross regional product (GRP);

- income from events in theatres;

- consumer price index (CPI);

- number of employees in the economy as a whole;

- number of visitors;

- number of budget allocations;

- theatre's expenditures;

- average wage of employees in theatres;

- average number of employees in theatres;

- average wages in the economy.
All initial financial indicators for each period have been used in current prices. To smooth the effect of price growth, which was 4.8 times for the period under review according to the Russian Federal State Statistics Service, the values have been adjusted to the prices of 2001 by using the GDP deflator. At the same time, the entire data has been presented both in the regional context and in the context of Federal districts and Russia as a whole. At the end of 2014, 24 theaters were under the Federal jurisdiction of the Ministry of Culture of the Russian Federation and 593 under local jurisdiction, distributed among 80 subjects of the country.

\section{PRIMARY DATA ANALYSIS}

In this research a well-known Baumol's indices have been used [6]:

Baumol's Index “ $B_{1}$ ”:

$$
B_{I}^{t+1}=\frac{\frac{V_{I}^{t+1}}{V_{E}^{t+1}}-\frac{V_{E}^{t+1}}{V_{E}^{t}}}{\frac{V_{I}^{t}}{V_{E}^{t}}}=\left[\left(\frac{V_{I}^{t+1}}{V_{E}^{t+1}}\right) /\left(\frac{V_{I}^{t}}{V_{E}^{t}}\right)\right]-1,
$$

where $V_{I}$ and $V_{E}$ - labor productivity indicators, respectively, in the sphere of patronized goods and the economy as a whole, in years $t$ and $t+1$.

Similar calculations have been used for index " $B_{2}$ ", that characterizes the catch-up in wage dynamics, and index " $B_{3}$ ”, which illustrates the outrunning growth of ticket prices in relation to the relevant parameters of macroeconomic dynamics, general Baumol's index 


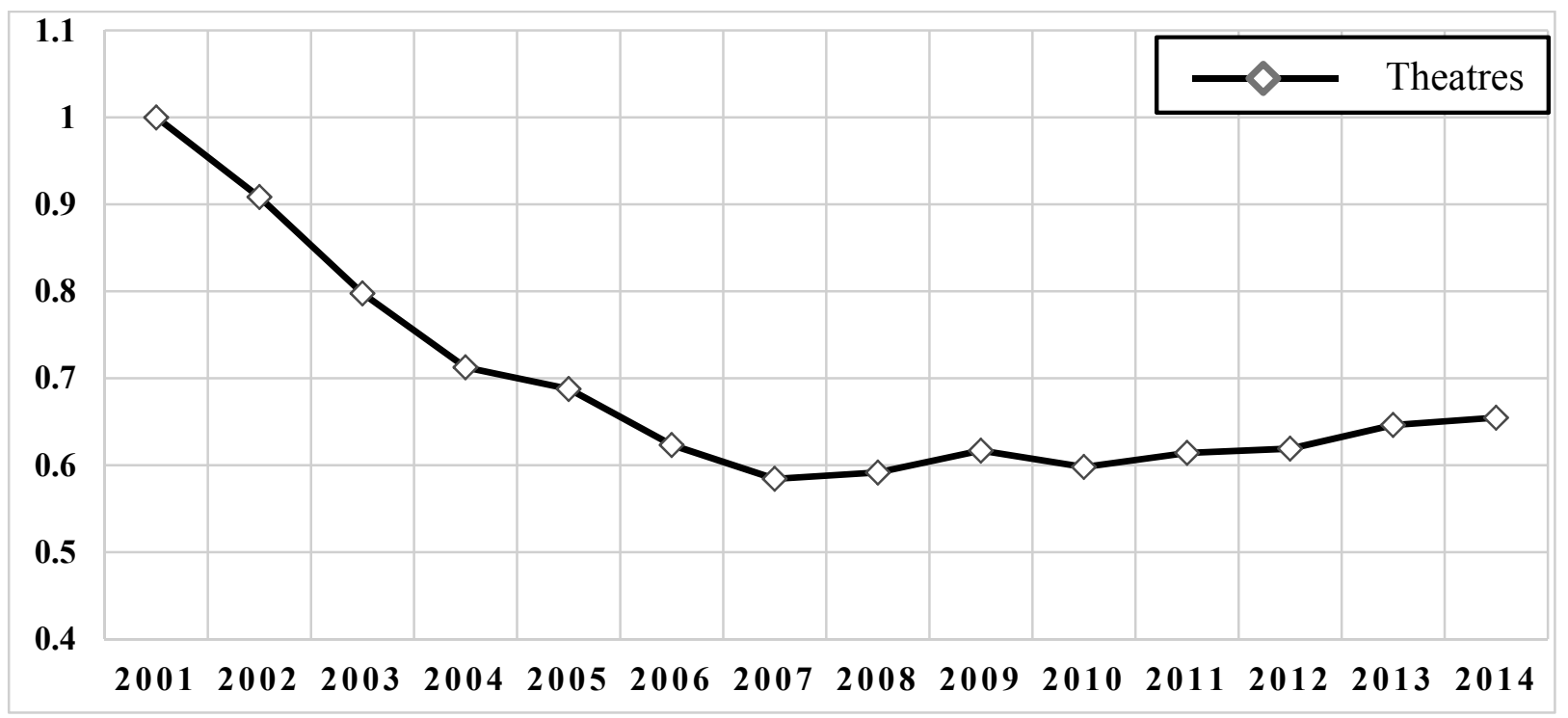

Fig. 2. Dynamics of index “ $\boldsymbol{B}_{1}$ " (in constant prices of 2001, 2001=1)

Source: the calculations done by the author.

" $B$ ", which measures the growth rate (by the base year) of the income deficit per visit, and its modification " $B$ " " - which reflects the dynamics of changes in the share of expenses, covered by budget subsidies. In this regard, the following table should be considered (Fig. 1).

The table shows that the dynamics of labor productivity in theaters in 2001-2004 had a downward trend. After that, until 2010 it remained approximately at the same level, and only by 2014 it reached the same level as in 2001. At the same time, the level of productivity in the country has steadily increased, and changed the vector of its development only in 2009. This allows us to talk about the growth of 1.5 times relative to the base year by the end of 2014 .

The data reveal a continuously widening gap between labor productivity in theatres and in the whole economy of the country. This confirms the hypothesis of "lagging labor productivity" of performing arts, formulated by Baumol and Bowen, and confirmed for Russia in the mentioned work of Rubinshteyn. A slight increase in 2012-2014 can be caused by the "May decrees" implemented by the President in 2012 and the "Year of culture" announced in 2014. However, the measures taken to strengthen the cultural economy are clearly insufficient, as evidenced by the steadily increasing gap in productivity in recent years (Fig. 2).

In this case, index " $B_{1}$ " - is the dynamics of the ratio of labor productivity in theaters to labor productivity in the economy calculated in constant prices in 2001 mainly to avoid the inflation on the analysis result. As shown in the picture (Fig. 2), despite some growth of this index since 2008, the line has a negative slope.
It indicates the increase in the labor productivity lag in theaters from the economy as a whole.

Next is the value of index " $B_{2}$ ", which reflects the dynamics of the ratio of average monthly wages in theaters to the average monthly wage in the economy. This confirms the hypothesis about independence of wage growth in theaters from labor productivity growth. It has been shown as a positive slope (Fig. 3).

The table allows shows the catch up dynamics of wage growth in theaters. If index " $B_{2}$ ” is considered in the context of the federation subjects, the situation doesn't look so clear. Thus, in the Ural FD wages in theaters in 2001 were significantly lower than in average in the economy of the federal district where index “ $B_{2}$ ” was 0.39 . Despite obvious problems in financing theatre activities in this region, in 2014 the value of this index increased to 0.71 . In the North-Western Federal district it was almost 1.36 , i.e. the wage in theatres was higher than the average wage in this district by one third (Fig. 4). In general, the hypothesis on the wage growth in this sphere of economic can be accepted in isolation from productivity growth.

The dynamics of index " $B_{3}$ ” should be considered as it reflects the ratio of tickets prices in theaters with the overall level of prices in the economy (Fig. 5).

As seen from the table, the values of index " $B_{3}$ " in the period under review were steadily rising. At the same time, in 2008-2010 and 2013-2014, there was a decrease in the index. The maximum value was recorded in 2013 at the level of 2.89 comparing to 2001. However, in 2014, index “ $B_{3}$ ” was 2.68. It follows that the theatre ticket prices were growing faster than CPI. 


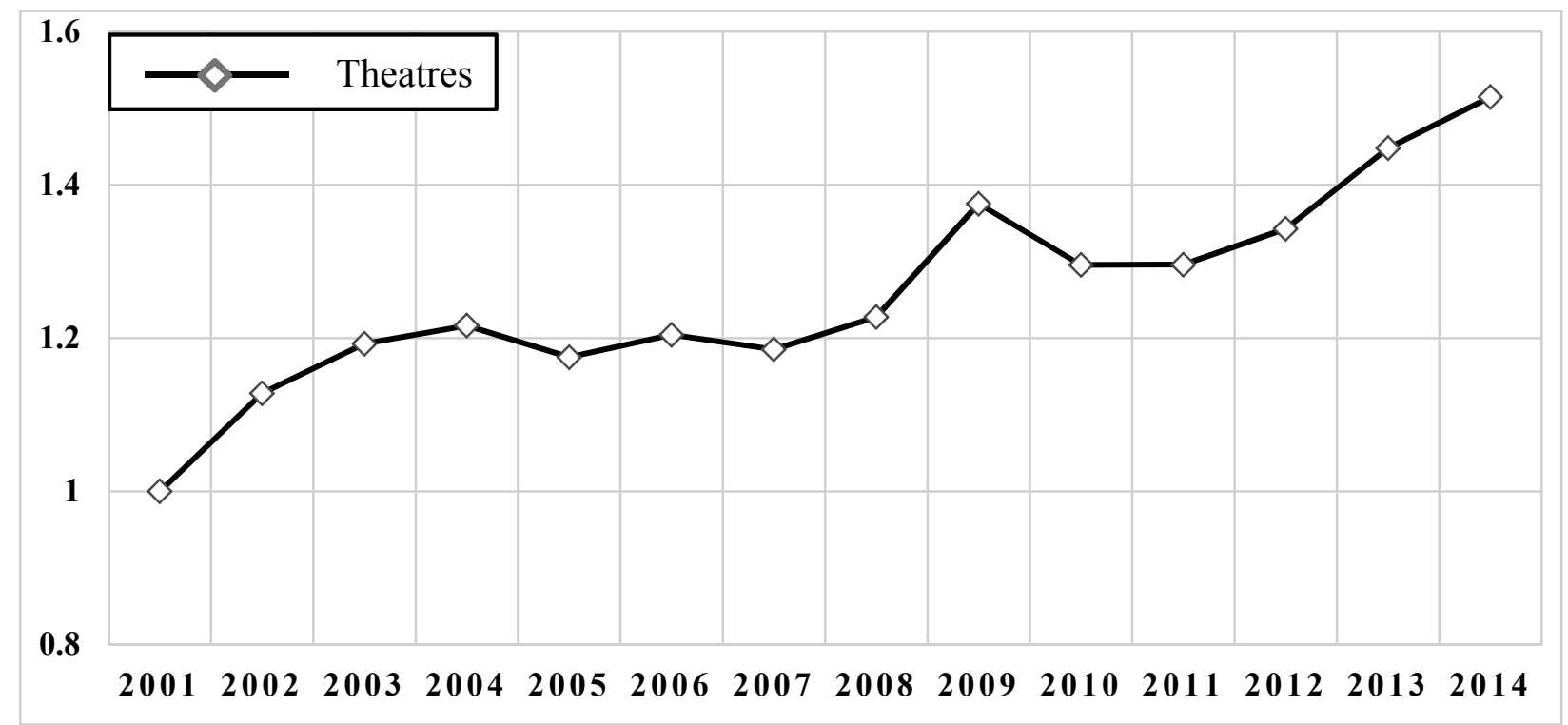

Fig. 3. Dynamics oindex " $B_{2}$ " (in constant prices of 2001, 2001=1)

Source: the calculations done by the author.

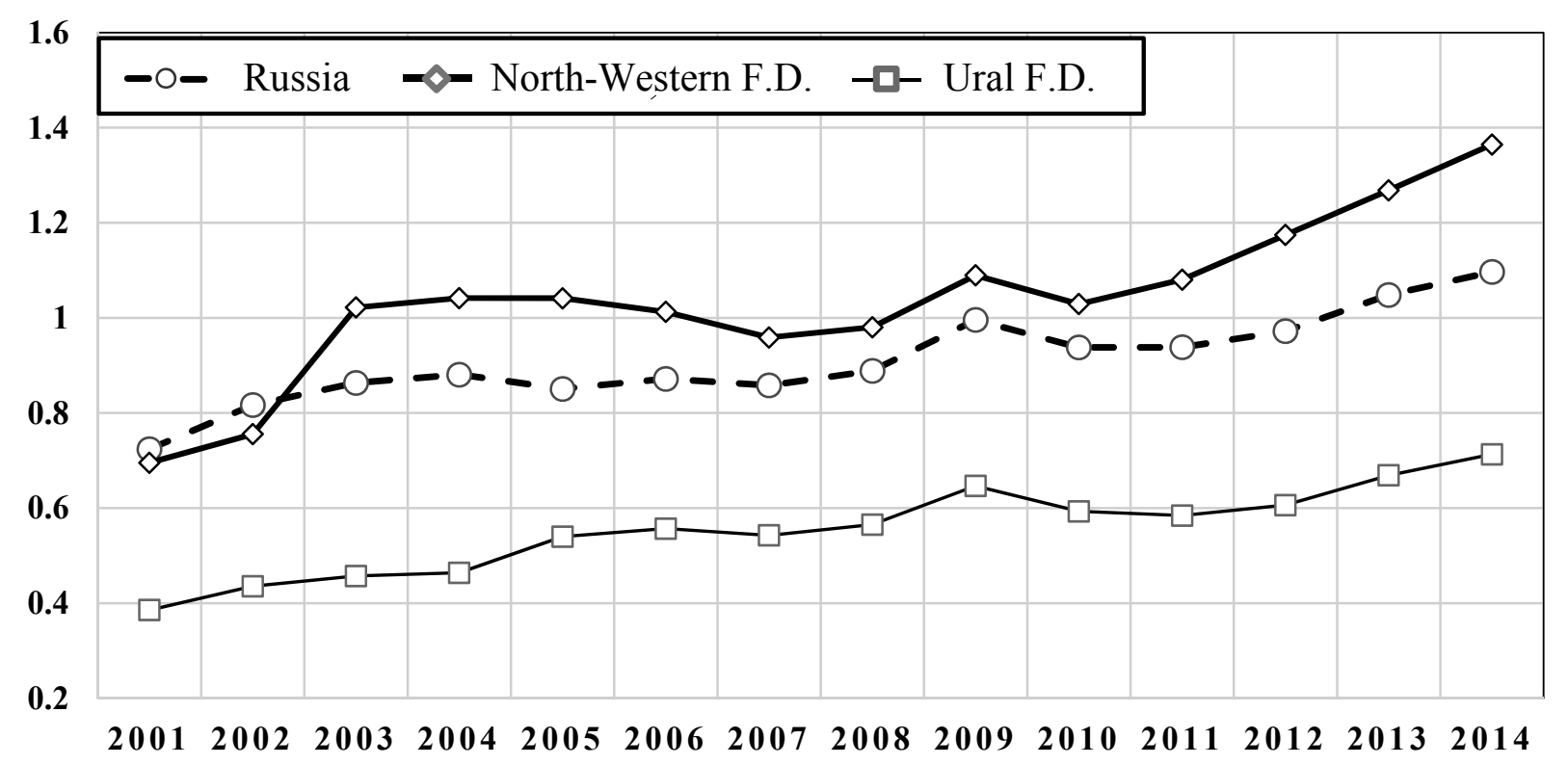

Fig. 4. Dynamics of index " $B_{2}$ ” in the NWFD, UFD and in Russia (in constant 2001 prices, 2001=1)

Source: the calculations done by the author.

This regularity for the period from 2001 to 2014 coincides with the result Rubinshteyn's publication [6].

The change of the Baumol's index " $B$ " should also be considered, as it measures the theatre income deficit per one visitor (Fig. 6).

The table shows that the income deficit has increased since 2001 over the considered period. Therefore, the result of the impact of the cost disease, namely, the inability to cover costs from own income is seen. It is particularly important to follow the dynamics of another indicator - “ $B$ ", which measures the share of expenditure covered by the budget allocations. The dynamics of this index is shown in the following table (Fig. 7).

Based on the graphical analysis, a certain increase can be mentioned in indicator " $B$ " "; the values of this index range from 1 to 1.25 . In this period, theaters needed support to cover their own costs. To understand what costs theaters were able to cover themselves due to ticket sales, it makes sense to consider another schedule (Fig. 8).

The results show that the share of expenses, covered by the income from their own activities, decreased over the considered period, with the maximum value of 0.24 it reached in 2001. It is possible 


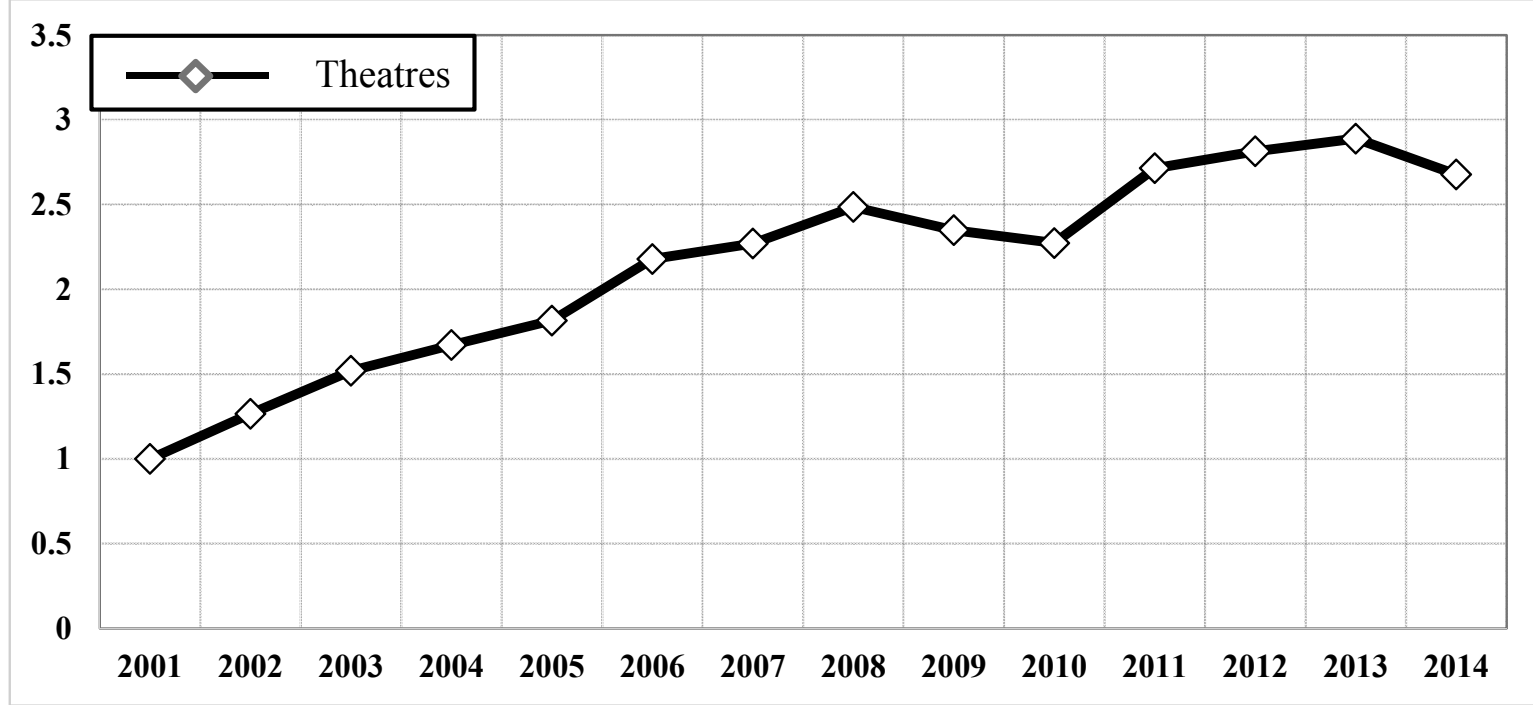

Fig. 5. Dynamics of index “ $B_{3}$ ” (in constant prices of 2001, 2001=1)

Source: the calculations done by the author.

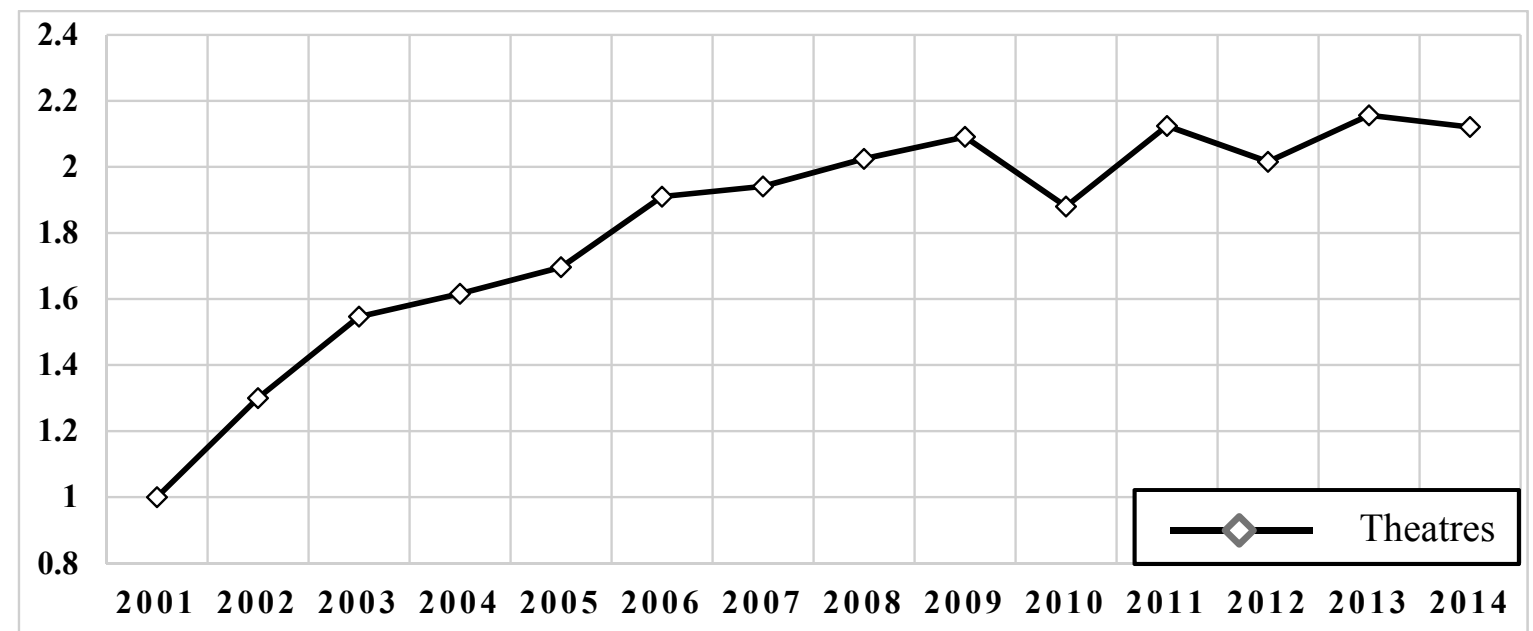

Fig. 6. Dynamics of index “ $B$ " (in constant prices of 2001, 2001=1)

Source: the calculations done by the author.

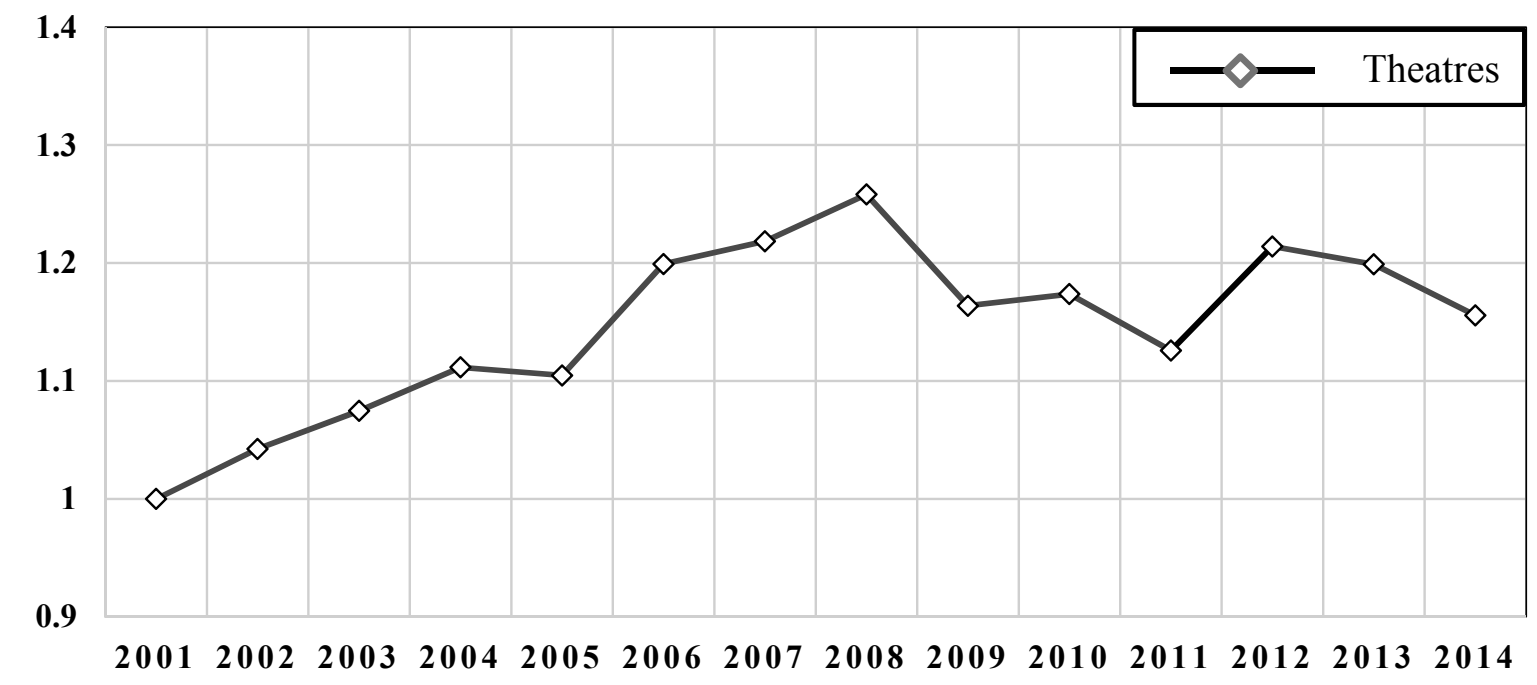

Fig. 7. Dynamics of index “ $\boldsymbol{B}^{* ”}(2001=1)$

Source: the calculations done by the author. 


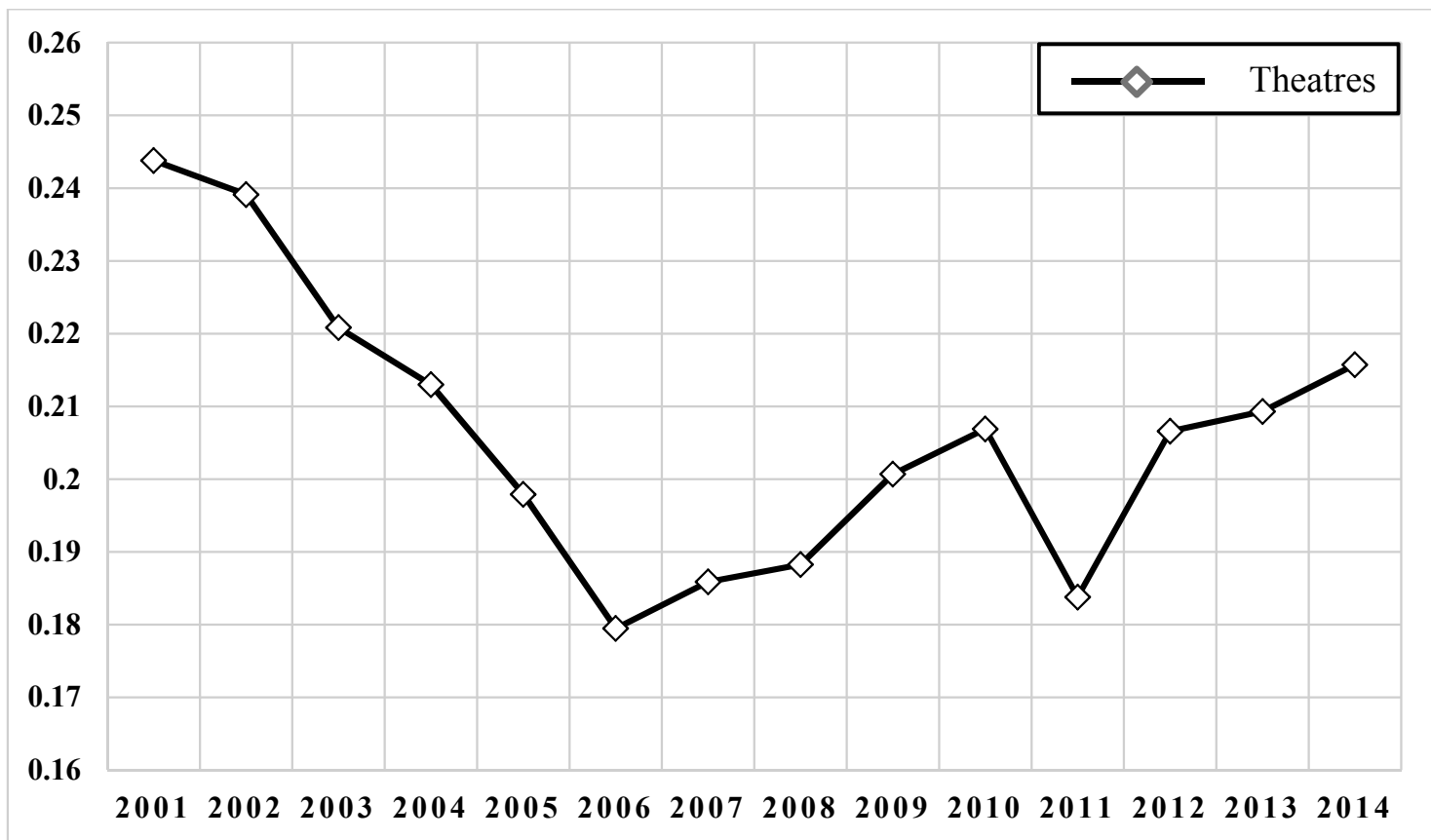

\section{Fig. 8. Share of expenses covered by ticket sales (\%)}

Source: the calculations done by the author.

to note a small increase from 2006 to 2010, but the value itself increased slightly from 0.18 to 0.20 . On the contrary, the share of budget funds in covering costs increased from 0.64 to 0.74 . Although, there was a decrease in this indicator from 2008 to 2011, its value always remained more than 0.60 . Therefore, it can be concluded that almost $70 \%$ of all expenses were covered only by the budget allocations. Theaters were able to cover about $20 \%$ of costs due to the tickets sales, and the remaining $10 \%$ were covered by commercial activities.

\section{ECONOMETRIC MODELING}

As mentioned above, the research presents the data for the period of 2001-2014 in Russia and the regions of the Russian Federation. It makes it possible to evaluate the status of these types of culture and to check cost disease in relation to the current stage of their development.

To begin with, the table of initial statistics of the calculated indicators should be analyzed (Tabl. 1). First of all, Jarque-Bera statistics has been used, the null hypothesis of which is that the data is normally distributed. Since the probability value for all variables is 0 , it can be concluded that the analyzed data is not normally distributed. This is also confirmed by the values of the coefficients of kurtosis and skewness, which are 3 and 0 , respectively, in the normal distribution. The calculations show that in this case the values of the analyzed indicators differ from the normal values.
Now, the available data for stationary should be check. For this, the test for panel data Levin, Lin \& Chu has been used where the null hypothesis indicates a unit root. The obtained probability values indicate that the null hypothesis has been rejected, therefore, all data are stationary (Tabl. 2).

The econometric model of the dependence of the income deficit on the calculated values of the Baumol's indices follows. This analysis will be carried out by using three main models.

\section{The pooled model of panel data.}

The choice of this method is due directly to the structure of statistical data, namely the values of the Baumol's coefficients for 80 regions of the Russian Federation for the period of 2001-2014. The equation of the model is as follows:

$$
B_{i t}=\beta_{0}+\beta_{1} B_{1 i t}+\beta_{2} B_{2 i t}+\beta_{3} B_{3 i t}+\varepsilon_{i t},
$$

where $B_{i t}$-is the value of income deficit in the $i$-th region, $\beta_{0}-$ is a constant coefficient, $B_{1} ; B_{2} ; B_{2}$ are the coefficients of the regression model; $B_{i t}$ - is the value of Baumol's indexes " $B_{1}$ ", " $B_{2}$ ", " $B_{3}$ " in the $i$-th region. Errors $\varepsilon_{i t}$ - are normal and mutually independent. Model estimates have been obtained by the least squares method (OLS).

The modification of the basic model is also calculated. Instead of " $B$ ”, the value of income deficit, indicator " $B$ " " is used - it characterizes the share of expenses covered by the budget subsidies. The modified model is as follows: 


\section{Summary statistics of indicators}

\begin{tabular}{|l|c|c|c|c|c|}
\hline & $\mathbf{B}$ & $\mathbf{B}_{1}$ & $\mathbf{B}_{2}$ & $\mathbf{B}_{\mathbf{3}}$ & $\mathbf{B}^{*}$ \\
\hline Mean & 1.922447 & 0.767922 & 1.169605 & 0.895463 & 1.065583 \\
\hline Median & 1.601830 & 0.743097 & 1.113832 & 0.822634 & 1.036792 \\
\hline Maximum & 15.57550 & 10.65582 & 2.665374 & 5.366528 & 6.505754 \\
\hline Minimum & 0.209104 & 0.103547 & 0.489517 & 0.150577 & 0.038214 \\
\hline Std, Dev, & 1.385603 & 0.389758 & 0.272180 & 0.480304 & 0.298152 \\
\hline Skewness & 5.417054 & 15.24755 & 1.488635 & 3.850281 & 10.63878 \\
\hline Kurtosis & 45.54463 & 381.4124 & 7.016783 & 27.79213 & 169.1881 \\
\hline Jarque-Bera & 87778.08 & 6563734. & 1138.482 & 30692.72 & 1278409. \\
\hline Probability & 0.000000 & 0.000000 & 0.000000 & 0.000000 & 0.000000 \\
\hline Sum & 2101.234 & 839.3384 & 1278.378 & 978.7408 & 1164.682 \\
\hline Sum Sq. Dev. & 2096.527 & 165.8875 & 80.89777 & 251.9154 & 97.07314 \\
\hline Observations & 1093 & 1093 & 1093 & 1093 & 1093 \\
\hline
\end{tabular}

Source: the calculations done by the author.

Test Levin, Lin \& Chu

\begin{tabular}{|c|c|c|c|c|}
\hline \multirow{2}{*}{} & \multicolumn{4}{|c|}{$\begin{array}{c}\text { The null hypothesis of a unit root by } \\
\text { Levin, Lin \& Chu test }\end{array}$} \\
\cline { 2 - 5 } & \multicolumn{2}{|c|}{ Original data } & \multicolumn{2}{c|}{ The logarithms of the data } \\
\cline { 2 - 5 } & Statistic & Prob. & Statistic & 0.0000 \\
\hline$B^{*}$ & -11.1978 & 0.0000 & -15.0479 & 0.0000 \\
\hline$B_{1}$ & -20.4508 & 0.0000 & -13.7904 & 0.0000 \\
\hline$B_{2}$ & -6.10965 & 0.0000 & -9.10863 & 0.0022 \\
\hline$B_{3}$ & -7.08662 & 0.0000 & -2.84503 & 0.0000 \\
\hline$B^{*}$ & -15.6797 & 0.0000 & -15.5254 & \\
\hline
\end{tabular}

Source: the calculations done by the author.

$$
B_{i t}^{*}=\beta_{0}+\beta_{1} B_{1 i t}+\beta_{2} B_{2 i t}+\beta_{3} B_{3 i t}+\varepsilon_{i t},
$$

where $B_{i t}^{*}-$ is the share of expenses is covered by the budget subsidies in the $i$-th region, $\beta_{0}$ - is a constant coefficient, $B_{i t}^{k}-$ is the value of Baumol's indexes " $B_{1}$ ", " $B_{2}$ ", " $B_{3}$ " in the $i$-th region.

2. The model of quantile regression.

The quantile regression is the process of estimating the parameters of linear dependence between explanatory variables and the specified quantile level of the explained variable. Unlike the usual OLS, quantile regression is a kind of a nonparametric estimation method. It gives the opportunity to get more information: to estimate the regression parameters for all quantiles of the distribution of the dependent variable. In addition, the model is significantly less sensitive to emissions in statistics and to violations of assumptions about the nature of distributions.

This approach eliminates the bias in the estimation results due to anomalous emissions that influence the average value of total Baumol's index characterizing the consequences of the cost disease. In 
Pair correlation

Table 3

\begin{tabular}{|c|c|c|c|c|c|}
\hline & $\mathbf{B}$ & $\mathbf{B}_{1}$ & $\mathbf{B}_{2}$ & $\mathbf{B}_{3}$ & $\mathbf{B}^{*}$ \\
\hline $\mathrm{B}$ & 1.000000 & -0.215717 & 0.130045 & 0.323569 & -0.110817 \\
\hline $\mathrm{B}_{1}$ & -0.215717 & 1.000000 & 0.087084 & -0.077716 & -0.079612 \\
\hline $\mathrm{B}_{2}$ & 0.130045 & 0.087084 & 1.000000 & -0.134132 & 0.037090 \\
\hline $\mathrm{B}_{3}$ & 0.323569 & -0.077716 & -0.134132 & 1.000000 & 0.028464 \\
\hline $\mathrm{B}^{*}$ & -0.110817 & -0.079612 & 0.037090 & 0.028464 & 1.000000 \\
\hline
\end{tabular}

Source: the calculations done by the author.

The coefficients of models № 1

Table 4

\begin{tabular}{|l|c|c|c|c|c|c|}
\hline \multirow{2}{*}{$\begin{array}{c}\text { Dependent } \\
\text { variable «B» }\end{array}$} & \multicolumn{7}{|c|}{ Explanatory variables } \\
\cline { 2 - 6 } & Const & $\mathbf{B}_{1}$ & $\mathbf{B}_{2}$ & $\mathbf{B}_{3}$ & $\mathbf{R}^{2}$ & $\begin{array}{c}\text { Number of } \\
\text { observations }\end{array}$ \\
\hline OLS & $0.478(0.204)^{* *}$ & $\begin{array}{c}-0.734 \\
(0.098)^{* * *}\end{array}$ & $\begin{array}{c}0.981 \\
(0.142)^{* * *}\end{array}$ & $0.962(0.080)^{* * *}$ & 0.18 & 1093 \\
\hline Quantile & $1.370(0.220)^{* * *}$ & $\begin{array}{c}-1.645 \\
(0.192)^{* * *}\end{array}$ & $\begin{array}{c}0.858 \\
(0.126)^{* * *}\end{array}$ & $0.417(0.142)^{* * *}$ & 0.05 & 1093 \\
\hline $\begin{array}{l}\text { Quantile with } \\
\text { logarithms }\end{array}$ & $0.150(0.023)^{* * *}$ & $\begin{array}{c}-0.818 \\
(0.039)^{* * *}\end{array}$ & $\begin{array}{c}0.733 \\
(0.070)^{* * *}\end{array}$ & $0.153(0.032)^{* * *}$ & 0.26 & 1093 \\
\hline
\end{tabular}

“***”, “**”, "** - meaning of the regression coefficients at $1 \%, 5 \%$ and $10 \%$, respectively.

Source: the calculations done by the author.

the research, the model of the quantile regression has been presented in the following way:

$$
\begin{gathered}
Q_{B_{i t}}\left(\tau \mid B_{1 i t}, B_{2 i t}, B_{3 i t}\right)= \\
=\beta_{0}+\beta_{1} B_{1 i t}+\beta_{2} B_{2 i t}+\beta_{3} B_{3 i t}, \tau=0.5,
\end{gathered}
$$

where $\tau-$ is the quantile level and takes values in between $(0 ; 1)$. If $\tau=0.5$, then, the model turns into a median (conditional median) regression. If to calculate the equation modification replacing the dependent variable by indicator " $B$ ".", the share of expenses covered by budget subsidies, the quantile regression will look as follows:

$$
\begin{gathered}
Q_{B_{i t}^{*}}\left(\tau \mid B_{1 i t}, B_{2 i t}, B_{3 i t}\right)= \\
=\beta_{0}+\beta_{1} B_{1 i t}+\beta_{2} B_{2 i t}+\beta_{3} B_{3 i t}, \tau=0.5 .
\end{gathered}
$$

3. The quantile regression model with logarithm data.

Considering that the original data are not distributed normally, logarithms of the data have been cal- culated for further study and the following quantile regressions have been constructed:

$$
\begin{gathered}
Q_{L n_{-} B_{i t}}\left(\tau \mid L n_{-} B_{1 i t}, L n_{-} B_{2 i t}, L n_{-} B_{3 i t}\right)= \\
=\beta_{0}+\beta_{1} L n_{-} B_{1 i t}+\beta_{2} L n_{-} B_{2 i t}+\beta_{3} L n_{-} B_{3 i t}, \tau=0.5 \\
\left.\quad Q_{1 n_{-} B_{i t}^{*}} \tau \mid L n_{-} B_{1 i t}, L n_{-} B_{2 i t}, L n_{-} B_{3 i t}\right)= \\
=\beta_{0}+\beta_{1} L n_{-} B_{1 i t}+\beta_{2} L n_{-} B_{2 i t}+\beta_{3} L n_{-} B_{3 i t}, \tau=0.5 .
\end{gathered}
$$

Before moving to the construction of econometric models, it is necessary to consider the correlation table and determine the impact of Baumol's indices on the income deficit and the share of costs covered by subsidies (Tabl. 3).

The calculations have showed that for index " $B$ " value, the correlation coefficients with the explanatory variables fluctuate modulo from 0.13 to 0.32 . Variable " $B_{1}$ " coefficient is negative, which suggests that with the lag of labor productivity in culture from the economy, 


\section{The coefficients of models № 2}

\begin{tabular}{|l|c|c|c|c|c|c|}
\hline \multirow{2}{*}{$\begin{array}{c}\text { Dependent variable } \\
\text { "B*" }\end{array}$} & \multicolumn{6}{|c|}{ Explanatory variables } \\
\cline { 2 - 7 } & Const & $\mathbf{B}_{1}$ & $\mathbf{B}_{2}$ & $\mathbf{B}_{3}$ & $\mathbf{R}^{2}$ & $\begin{array}{c}\text { Number of } \\
\text { observations }\end{array}$ \\
\hline OLS & $1.036(0.048)^{* * *}$ & $\begin{array}{c}-0.062 \\
(0.023)^{* * *}\end{array}$ & $0.053(0.033)$ & $\begin{array}{c}0.018 \\
(0.019)\end{array}$ & 0.009 & 1093 \\
\hline Quantile & $0.949(0.035)^{* * *}$ & $\begin{array}{c}-0.090 \\
(0.025)^{* * *}\end{array}$ & $\begin{array}{c}0.112 \\
(0.017)^{* * *}\end{array}$ & $\begin{array}{c}0.029 \\
(0.015)^{*}\end{array}$ & 0.05 & 1093 \\
\hline Quantile with & 0.000 & $\begin{array}{c}-0.073 \\
(0.014)^{* * *}\end{array}$ & $\begin{array}{c}0.142 \\
(0.018)^{* * *}\end{array}$ & $\begin{array}{c}0.031 \\
(0.012)^{* *}\end{array}$ & 0.06 & 1093 \\
\hline
\end{tabular}

**,",***,",**, -eaning of the regression coefficients at $1 \%, 5 \%$ and $10 \%$, respectively.

Source: the calculations done by the author.

the income deficit will increase. For indicator “ $B$ " ”, the coefficients vary from 0.028 to 0.079 , while the ratio of signs at the coefficients is similar to index " $B$ ”. The direct results of evaluation of all three models are presented below (Tabl. 4).

Due to the received results, it can be said that for different model evaluation options, all coefficients for explanatory variables are significant at $1 \%$ level. It is important to note that the coefficient for variable " $B_{1}$ ", which reflects the relationship between productivity in theaters and productivity in the economy, is negative in all models. This suggests that with the lag in labor productivity, the income deficit in theaters will only increase. The coefficients for " $B_{2}$ ” and " $B_{3}$ ” are positive in all models. This indicates an increasing deficit with above-average growth of wages and ticket prices. Based on this, it can be concluded that the increase in ticket prices does not reduce the income deficit in theaters. Below are the results of the evaluation of the modified model (Tabl. 5).

For variable " $B$ " " the results are slightly different. When evaluating the model by the OLS method, it has been found out that only indicator " $B_{1}$ ” is negative. At $1 \% \mathrm{v}$ has significant impact on the share of costs covered by subsidies, while " $B_{2}$ " and " $B_{3}$ " are insignificant. However, in case of quantile regression, the coefficients are all significant, with all variables being significant at $1 \%$ level and " $B_{3}$ ” at $10 \%$ level. After the logarithms model has been introduced, it the improvement in the value of coefficient " $B_{3}$ " can be noted. It is now significant at $5 \%$ level. Considering that the original data are not normal, with the introduction of the quantile regression (median) and logarithms, smoothing of the data takes place. This leads to an increase in the significance of the coefficients. At the same time, the regularities, typical for “ $B$ ", are used for " $B$ ". With the lag in labor productivity, advanced wage growth and super-inflationary growth of ticket prices, share of costs, covered by budget subsidies, will increase.

The results ofhe evaluation of these two models show that if the current trends continue, thso " $B_{1}$ ", the growth of " $B_{2}$ " and " $B_{3}$ ", the income deficit will increase. Thus, the costs will exceed the revenues from its own activities, which will result in the fact, that the costs of theaters will be covered only by budget subsidies (the growth of " $B$ "). This regularity has been completely confirmed by all three constructed econometric models.

The highest coefficient of determination is observed in the $3 r d$ model, i.e. in the quantile regression for logarithm data. However, the value of coefficient $R^{2}=0.26$ for " $B$ " and $R^{2}=0.06$ for " $B$ ", which is not high enough.

To evaluate the effect of price changes and other parameters on the income deficit value, the values of the average elasticity coefficients have been calculated. The estimates received by means of the following formula have been considered:

$$
E_{B_{i}}^{B}=\beta_{i} \times \frac{\overline{B_{i}}}{\bar{B}}, \quad i=1,2,3,
$$

where $E_{B_{i}}^{B}$ - is the average elasticity coefficient value of income deficit " $B$ " of the Baumol's coefficients, $\beta_{i}$-is the regression coefficient value at $B_{i}, \bar{B}_{i}-$ is the average value of the Baumol's coefficients, $\bar{B}-$ is the average value of income deficit. Elasticity has been calculated for " $B$ " " in the same way. The analysis of the results is presented in Tabl. 6 . 
The value of the average coefficient of elasticity

\begin{tabular}{|l|c|c|c|c|c|c|}
\hline & \multicolumn{3}{|c|}{ OLS } & \multicolumn{3}{c|}{ Quantile } \\
\hline & $\beta_{1}$ & $\beta_{2}$ & $\beta_{3}$ & $\beta_{1}$ & $\beta_{2}$ & $\beta_{3}$ \\
\hline$\beta$ & -0.29338 & 0.596834 & 0.448093 & -0.6571 & 0.593792 & 0.208675 \\
\hline$\beta^{*}$ & -0.04468 & 0.058174 & 0.015126 & -0.06486 & 0.122933 & 0.02437 \\
\hline
\end{tabular}

Source: the calculations done by the author.

The result received allow to see the negative elasticity of income deficit of Baumol's index " $B_{1}$ " and the positive elasticity of the Baumol's indices " $B_{2}$ " and " $B_{3}$ ". The same sign ratio is maintained for modified Baumol index " $B$ ". It is important to note, that the modulus of all coefficients is less than 1 , therefore, elasticity is relatively weak. Thus, the deficit or share of costs, covered by subsidies, causes poor reaction to the changes in any of Baumol's indices and changes insignificantly.

\section{INSTITUTIONS OF CULTURE FINANCING}

If to mention the current economic situation of culture in Russia, it should be noted that the economic system development constantly faces serious difficulties. They consist in reduced growth rates of national production, weakening of the national currency, problems of the deficit of budget system. Such trends, in many ways, create an unfavorable situation for culture. As shown in the previous section, this situation is subject to the phenomenon of cost disease. Taking into account the nominal reduction of Federal budget expenditures on culture by more than $16.5 \%$ until 2020 (in relation to expenditures in 2017), and the practice of limited budget financing of cultural organizations in the regions developed in recent years, it is necessary to pay attention to the system of distribution of funds.

It is obvious that the growing needs of cultural institutions in the budget allocations, subject to the declining funding of culture, can't be fully met. Due to the growing shortage of income, there is a need to find additional resources to finance cultural organizations. To find the best way to financially support organizations, the formation of institutions of public support for organizations can become an actual direction in the development of this sector of the economy.

In international experience, lack of public funding is often compensated by increasing public support and creating new forms of interaction between citizens and cultural organizations in need of additional income or reducing costs. The "bottlenecks" of public administration in financial support of culture can be eliminated with the help of institutions of civil activity, able to adjust the decisions of local authorities. Also, by ordinary citizens participation in the selection of priority areas of development.

The first group of the institutes consists mainly of charity institutes existing both abroad and in Russia. Within this group 2 main groups of institutions can be distinguished:

1) institutions that save financial expenses of cultural institutions, as well as institutions that attract additional financial resources: institute of volunteering, crowdsourcing, crowdfunding, patronage of arts, NPO and various funds.

2) institutions of civil activity in the redistribution of public finances: institute of proactive budgeting, institute of individual budget allocations.

The first group of institutions is based on the principle of impact on culture organizations by increasing or saving their resources. It is important for improving the financial situation of art institutions. However, these mechanisms imply additional (including financial) burden on citizens. Therefore, in a difficult economic situation in the country, institutions of different content become particularly important.

It should be kept in mind that the main task is the distribution of the resources already collected by 
the state. In particular, the budget of any size can be directed to social needs, and on the contrary, to other areas of the function of state and society.

In this regard, a particularly notable topic for study is institutions that allow citizens to independently participate in the distribution of budgetary funds, despite their small amounts.

One such institution for redistributing resources, which allows managing funds at the municipal level, is the institution of proactive budgeting. It has recently become very popular. This institution is a mechanism of budget redistribution. It allows citizens who do not participate in political processes and election campaigns to vote how to spend budget.

This initiative was first launched in Latin America in the late 1980s and early 1990s and since then has gained popularity in North America, Europe and a number of Asian countries. The features of successful implementation of such institutions are: political will and sufficient material support of the state, developed civil society and support from local governments.

In modern practice of the Russian Federation, this institution was initially presented by the "Support program for local initiatives" (SPLI), provided by the World Bank in 2007. Back then, the program started in the eastern regions of the Stavropol region. Today, the development and implementation of this institution is supported by a joint project of the Ministry of Finance of the Russian Federation and the World Bank in the framework of program of improving efficient management of public and municipal finances for the period up to 2018 "Ensuring openness and transparency of public finances” (approved in 2013). It involves joint financing of the most popular projects at the municipal level, both by citizens and by the state.

Another public institution of budget redistribution is the institute of individual budget allocations (IBA).

IBA, as well as the institute of proactive budgeting, contains the mechanism of redistribution of budgetary funds. However, if the previous institution performs additional project work at the municipal level, the IBA should become a direct add-on to the existing tax system. According to the preferences of every citizen, this mechanism provides them with a choice of priority expenditures of a small part of the budget in the range of $2 \%$, paid personal income tax.

The main distinguishing feature of this institute is the decision to finance certain areas, including culture. It covers the territory of the whole country. At the same time, this possibility must be enshrined in law in such a way that the chosen decision was final and there would be no possibility for the authorities to review it.
The institute of individual budget allocations provides citizens with the right to vote for ways of spending a limited part of the state's tax revenues. The development of the Institute of "interest philanthropy" is peculiar to European countries. The basis of the "interest philanthropy" model was the Western European practice of Italy and Spain, where income tax deductions were mainly used for financial support of the Catholic Church and to a far lesser degree for other social and cultural needs. However, in Hungary, in the mid-1990s, a new format of the existing institution was proposed, considering the current socio-economic situation in the country and the level of philanthropy. After the so-called " $1 \%$ law" was implemented in December, 1996, individuals were given the right to direct $1 \%$ of the income tax, paid in the last tax period, to the selected budget organization or non-profit organization, including those of culture. Non-profit organizations in Hungary, inspired by the new opportunities offered by the law, conducted a mass campaign among the population to report on their activities, thus, creating an extensive base of recipients.

\section{CONCLUSION}

The research leads to a few important conclusions. First, the lag in productivity in theaters from the economy as a whole stays on new data and on a new time interval. As for wages, there is an increase in coefficient " $B_{2}$ ", that is a reduction in the gap between wages in theaters and the economy as a whole. Primarily due to the "May decrees" introduced by the President of the Russian Federation in 2012, the gap reduction is not observed in all Federal districts. At the same time, there is a strong regional differentiation in the value of coefficient " $B_{2}$ " - not in all regions the wage in theaters has reached the regional level and can be only half of its level.

Second, the econometric analysis has confirmed the results of the work [6] in the nature of Baumol's coefficients' influence on the income deficit value. Although the models were based on the latest, more extensive data, during the period when the country was experiencing economic recovery and GDP growth, the research has still resulted in lagging labor productivity in theaters from the national level in the economy, contributing to the deficit increase. Strengthening wage growth in theatres and inflationary ticket price increases effect positively on the deficit increase.

Third, the impact of Baumol's coefficients on such an indicator as share of expenditures covered by budgetary subsidies has been considered. For this modified 
indicator the se regularities, as for the level of income deficit, remain. Their relationship can be mentioned. If the lagging productivity, wage growth and ticket prices rise contribute to the deficit growth and reduce their income from direct activities, then, theaters will be able to cover their costs only by direct government support. Therefore, the share of expenses covered by subsidies will increase. This has been observed in the course of work.

The fourth, this research has confirmed the hypothesis of slightly positive elasticity of demand for ticket prices. Thus, the growth of ticket prices is not a means to reduce specific revenue deficit.

Consequently, it can be concluded that theaters have still been subject to the cost disease. They ne

ed direct state subsidies. At the same time, considering this feature, "competent" cultural policy should be developed and implemented. It is important to note, that today budget subsidies are not the only way to support theaters and other cultural institutions. It is necessary to develop the existing institutions and introduce new alternative institutions of support from civil society, which are successfully used in many countries [27]. Such institutions can be divided into 2 groups.

The first group includes institutions of charity that exist both abroad and in Russia. In this group, institutes that economize of financial expenses of cultural institutions can be identified:

- institute of volunteerism,

- crowdsourcing,

and also, institutions of attracting additional financial resources for cultural institutions:

- crowdfunding,

- patronage of arts,

- NPO and various foundations.

The second group is a mechanism of interaction between the state and the society while selecting priority areas of budget financing:

- institute of proactive budgeting,

- institute of individual budget allocations (IBA).

These institutions are fundamentally new for the Russian practice of self-government. It is necessary to activate civil society and significant state support for their creation and functioning. Based on the experience of using these institutions in different countries, the second group has a strong potential for financial support to cultural institutions. The combination of all the above-mentioned institutions with the ward of the state will contribute to sufficient funding and sustainable development of the economics of culture.

\section{REFERENCES}

1. Rubinstein A., Muzychuk V. Optimization or degradation? Between the past and the future of Russian culture. Obshchestvennye nauki i sovremennost' $=$ Social Sciences and Contemporary World. 2014;(6):5-22. (In Russ.).

2. Last A.-K., Wetzel H. Baumol's cost-disease, efficiency, and productivity in the performing arts: An analysis of German public theaters. Journal of Cultural Economics. 2011;35(3):185-201. DOI: 10.1007/s10824-0119143-5

3. Baumol W., Bowen W. Performing arts, the economic dilemma: A study of problems common to theater, opera, music, and dance. New York: Twentieth Century Fund; 1966.582 p.

4. Nordhaus W. Baumol's diseases: A macroeconomic perspective. The B.E. Journal of Macroeconomics. 2008;8(1):1-39. DOI: 10.2202/1935-1690.1382

5. Fernandez R., Palazuelos L. European Union economies facing “Baumol's disease” within the service sector. JCMS: Journal of Common Market Studies. 2012;50(2):231-249. DOI: 10.1111/j.1468-5965.2011.02222.x

6. Rubinstein A. Patronized goods in the sphere of culture: "Price disease" features and effects. Moscow: RAS Institute of Economics; 2012.78 p. URL: https://inecon.org/images/stories/nauchnaya-jizn/kruglye-stoly/ Rubinstein_20120216.pdf (accessed 16.06.2018). (In Russ.)

7. Rubinshtein A. Studying "sponsored goods" in cultural sector. Symptoms and consequences of Baumol's cost disease. Part I. Creative and Knowledge Society. 2012;2(2): 35-57. DOI: 10.2478/v10212-011-0024-2

8. Rubinshtein A. Studying "sponsored goods" in cultural sector. Econometric model of Baumol's disease. Part II. Creative and Knowledge Society. 2013;3(1):28-48. DOI: 10.2478/v10212-011-0029-x

9. Abbing H. Let's forget about the cost disease. 2005. URL: http://www.hansabbing.nl/DOCeconomist/ Let's\%20forget\%20about\%20cost\%20disease\%20A5\%20version\%20060702.pdf (accessed 01.11.2018).

10. Seaman B. Empirical studies of demand for the performing arts. In: Handbook of the economics of art and culture. Vol. 1. Amsterdam: North-Holland Publ.; 2006: 415-472. DOI: 10.1016/S 1574-0676(06)01014-3

11. Avtonomov Yu. Empirical studies of demand for cultural goods: Performing arts and cultural heritage objects. Moscow: RAS Institute of Economics; 2011. 57 p. URL: https://inecon.org/images/stories/ nauchnaya-jizn/konverensii/Avtonomov.pdf (accessed 16.06.2018). (In Russ.) 
12. Throsby C., Withers G. The economics of the performing arts. New York: St. Martin's Press; 1979. 348 p.

13. West E. Subsidizing the performing arts. Toronto: Ontario Economic Council. 1985. $141 \mathrm{p}$.

14. Moore T. The demand for Broadway theater tickets. The Review of Economics and Statistics. 1966;48(1):7987. DOI: $10.2307 / 1924860$

15. Moore T. The economics of the American theater. Durham: Duke University Press; 1968. 192 p.

16. Houthakker H., Taylor L. Consumer demand in the United States, 1929-1970: Analyses and projections. Cambridge: Harvard University Press; 1970. 214 p.

17. Gapinski J. Economics, demographics, and attendance at the symphony. Journal of Cultural Economics. 1981;5(2):79-83. DOI: 10.1007/BF02221371

18. Felton M. Major influences on the demand for opera tickets. Journal of Cultural Economics. 1989;13(1):5364. DOI: $10.1007 /$ BF00219713

19. Luksetich W., Lange M. A simultaneous model of nonprofit symphony orchestra behavior. Journal of Cultural Economics. 1995;19(1):49-68. DOI: 10.1007/BF01074432

20. Forrest D., Grimes K., Woods R. Is it worth subsidizing regional repertory theatre? Oxford Economic Papers. 2000;52(2):381-397. DOI: 10.1093/oep/52.2.381

21. Corning J., Levy A. Demand for live theater with market segmentation and seasonality. Journal of Cultural Economics. 2002;26(3):217-235. DOI: 10.1023/A:1015673802364

22. Kirchgässner G., Pommerehne W. The decline of conventional culture: The impact of television on the demand for cinema and theatre performances. In: Grant N.K., Hendon W. S., Owen V.L., eds. Economic efficiency and the performing arts. Akron, OH: Association for Cultural Economics; 1986:44-61.

23. Schimmelpfennig J. Demand for ballet: A non-parametric analysis of the 1995 Royal Ballet summer season. Journal of Cultural Economics. 1997;21(2):119-127. DOI: 10.1023/A:1007431510546

24. Felton M. Evidence of the existence of the cost disease in the performing arts. Journal of Cultural Economics. 1994;18(4):301-312. DOI: 10.1007/BF01079761

25. Gapinski J. The lively arts as substitutes for the lively arts. The American Economic Review. 1986;76(2):20-25.

26. Heilbrun J. Growth, accessibility and the distribution of arts activity in the United States: 1980 to 1990. Journal of Cultural Economics. 1996;20(4):283-296. DOI: 10.1007/s10824-005-3296-Z

27. Nelson D. Hope for democracy: 25 years of participatory budgeting worldwide. 2014. 495 p. URL: http://www.in-loco.pt/upload_folder/edicoes/1279dd27-d1b1-40c9-ac77-c75f31f82ba2.pdf (accessed 01.11.2018).

\section{ABOUT THE AUTHORS}

Nikita A. Burakov - post-graduate student of the Institute of Economics of the RAS, Moscow, Russia burakovn@gmail.com

Olga A. Slavinskaya - post-graduate student of the Institute of Economics of the RAS, Moscow, Russia o.a.slavinskaya@gmail.com

\section{ИНФОРМАЦИЯ ОБ АВТОРАХ}

Никита Александрович Бураков - аспирант Института экономики Российской академии наук, Москва, Россия burakovn@gmail.com

Ольга Александровна Славинская - аспирант Института Экономики Российской академии наук, Москва, Россия

o.a.slavinskaya@gmail.com

The article was received 11.09.2018; accepted for publication 12.11.2018.

The authors read and approved the final version of the manuscript.

Статья поступила 11.09.2018; принята к публикации 12.11.2018.

Авторы прочитали и одобрили окончательный вариант рукописи. 